\title{
EVALUACIÓN DE TRAMPAS DE COLORES PARA TRIPS DEL MANGO ATAULFO EN EL SOCONUSCO, CHIAPAS*
}

\author{
EVALUATION OF COLOR TRAPS FOR THE MANGO ATAULFO \\ THRIPS IN THE SOCONUSCO, CHIAPAS
}

\author{
Armando Virgen Sánchez ${ }^{1}$, Antonio Santiesteban Hernández ${ }^{1}$ Leopoldo Cruz-López ${ }^{1 \S}$ \\ 'Departamento de Entomología. El Colegio de la Frontera Sur. Tapachula, Chiapas, México. C. P. 30700. Tel. 01962 6289800. Ext. 5453, 5452, 5455. (avirgen@ecosur. \\ mx), (asanties@ecosur.mx). \$A Autor para correspondencia: 1cruz@ecosur.mx.
}

\section{RESUMEN}

En este trabajo se evaluaron trampas de colores para capturar trips en árboles de mango cv. Ataulfo en el Soconusco, Chiapas, México. Se compararon trampas pegajosas de color azul, amarillo y violeta. Se colocó una trampa de cada color por árbol y se evaluaron en 5 árboles. Los resultados mostraron que se capturaron significativamente más trips en las trampas de color violeta.

Palabras clave: ataulfo, mango, preferencia color, trampas pegajosas, trips.

En el Soconusco, Chiapas, México, se cultivan alrededor de 18300 ha de mango cv. Ataulfo; sin embargo, el rendimiento es de $5.8 \mathrm{t} \mathrm{ha}^{-1}$ (Lee Rodríguez et al., 2006) atribuido a varios factores limitantes, entre ellos se encuentran las enfermedades y las plagas, de éstas últimas sobresale la mosca de la fruta, principalmente Anastrepha ludens (Loew) y desde hace varios años se ha reportado la presencia de grandes poblaciones de trips (Virgen et al., 1996).

Esquinca et al. (2004) reportaron que las inflorescencias con poblaciones mayores de 1500 trips, presentan bajo amarre de frutos. La manera que los productores han

\section{ABSTRACT}

In this paper colored traps were evaluated to capture thrips in mango cv. Ataulfo trees in Soconusco, Chiapas, Mexico. Sticky traps were compared in different colors: blue, yellow and violet. It was placed a trap of each color per tree and they were evaluated in five trees. The results showed that significantly more thrips were caught in violet traps.

Key words: Ataulfo, mango, color preference, sticky traps, thrips.

In Soconusco, Chiapas, Mexico, about 18300 ha of mango cv. Ataulfo are cultivated; however the yield is $5.8 \mathrm{t} \mathrm{ha}^{-1}$ (Lee Rodríguezetal., 2006) attributed to several limiting factors, these include diseases and pests, suchas thefruitfly,mainly Anastrepha ludens (Loew) and for several years it have been reported the presence of large populations of thrips (Virgen et al., 1996).

Esquinca et al. (2004), reported that inflorescence with populations greater than 1500 thrips, have low fruit set. The producers' way to attempt to control these insects has been using pesticides, and it has not been successful. For these reasons, in this paper color traps were evaluated, to know what color attracts more thrips in mango cultivation, in order to have a tool that allows monitoring these insects' populations.

\footnotetext{
* Recibido: octubre de 2010

Aceptado: junio de 2011
} 
intentado controlar a estos insectos, ha sido por medio de plaguicidas; cabe mencionar que no han tenido éxito. Por las razones antes mencionadas, en este estudio se evaluaron trampas de colores, para conocer cuál es el color que atrae más a los trips en el cultivo de mango; con el fin de contar con una herramienta que permita monitorear las poblaciones de estos insectos.

El presente trabajo se realizó en dos huertos representativos de la región: el "Rancho Cazanares" de 100 ha, que se ubica en el km 24 de la carretera a Puerto Madero, municipio de Tapachula, Chiapas y el "Rancho Palma de Oro" de 50 ha, ubicado en el km 2 de la carretera a Jaritas, municipio de Tapachula, Chiapas. Las trampas consistieron en piezas de cartón de $20 * 20 \mathrm{~cm}$ forradas de papel lustre en ambos lados y recubiertas con pegamento (Stikem Seabright, ${ }^{\circledR}$ Emery-Ville, California, USA), los colores del papel lustre que se evaluaron fueron: violeta, azul, y amarillo (Hoddle et al., 2002; Chu et al., 2006).

Las trampas se colocaron a $3 \mathrm{~m}$ de altura, dejando un espacio entre las brácteas de las inflorescencias y la trampa de $20 \mathrm{~cm}$. Se utilizaron cinco árboles, con tres trampas, una de cada color, distribuidas en cada árbol por una semana, después de este periodo fueron sustituidas por trampas nuevas registrándose el número de insectos capturados. Se realizaron tres repeticiones entre enero y marzo 2007, en los dos huertos. El diseño experimental utilizado fue de bloques al azar, los datos fueron analizados por medio de ANOVA de una vía y por prueba de comparación de medias de Tukey $(p \leq 0.05)$.

Los resultados mostraron que los trips fueron más atraídos al color violeta, tanto para el huerto Cazanares $(\mathrm{F}=33.87, \mathrm{GL}=2.42, p=0.001)$ como en Palma de oro $(\mathrm{F}=$ 56.19. $\mathrm{GL}=2.42, p=0.008$ ) (Figura 1a, 1b) comparado con el amarillo o el azul. El color amarillo es preferido por varias especies de trips en otros cultivos (Peña et al., 1993; González-Hernández et al., 1999) otras especies son atraídas al color azul (Chen et al., 2004) pero no se ha reportado el color violeta. En varias especies de trips el uso de trampas de colores representa una herramienta para registrar fluctuaciones de las poblaciones, como es el caso de Frankliella occidentalalis (Pergande) en diversos cultivos hortícolas y ornamentales (Johansen, 2000).
This research was conducted in two representative orchards of the region: "Rancho Cazanares" of 100 ha, located at km 24 of the road to Puerto Madero, in Tapachula, Chiapas and "Rancho Palma de Oro" of 50 ha, located at km 2 on the road to Jaritas, in Tapachula, Chiapas. The traps consisted of 20 pieces of cardboard $20 * 20 \mathrm{~cm}$, covered with luster paper on both sides and coated with glue (Stikem Seabright, ${ }^{\circledR}$ Emery-Ville, California, USA), the evaluated luster paper colors were: violet, blue and yellow (Hoddle et al., 2002; Chu et al., 2006).

The traps were placed $3 \mathrm{~m}$ height, leaving a space between the bracts of inflorescences and the $20 \mathrm{~cm}$ trap. Five trees were used with three traps, one of each color, distributed in each tree for a week, after this period the traps were replaced by new ones recording the number of captured insects. Three repetitions were conducted between January and March 2007 in both orchards. The randomized block design was used; data were analyzed using ANOVA and Tukey range test $(p \leq 0.05)$.

The results showed that thrips were more attracted to the violet color, both in Cazanares orchard $(\mathrm{F}=33.87, \mathrm{GL}=2.42$, $p=0.001)$ as well as Palma de Oro orchard $(\mathrm{F}=56.19 . \mathrm{GL}=$ 2.42, $p=0.008$ ) (Figure 1a, 1b), compared with yellow or blue. Yellow is preferred by several thrips species in thercrops

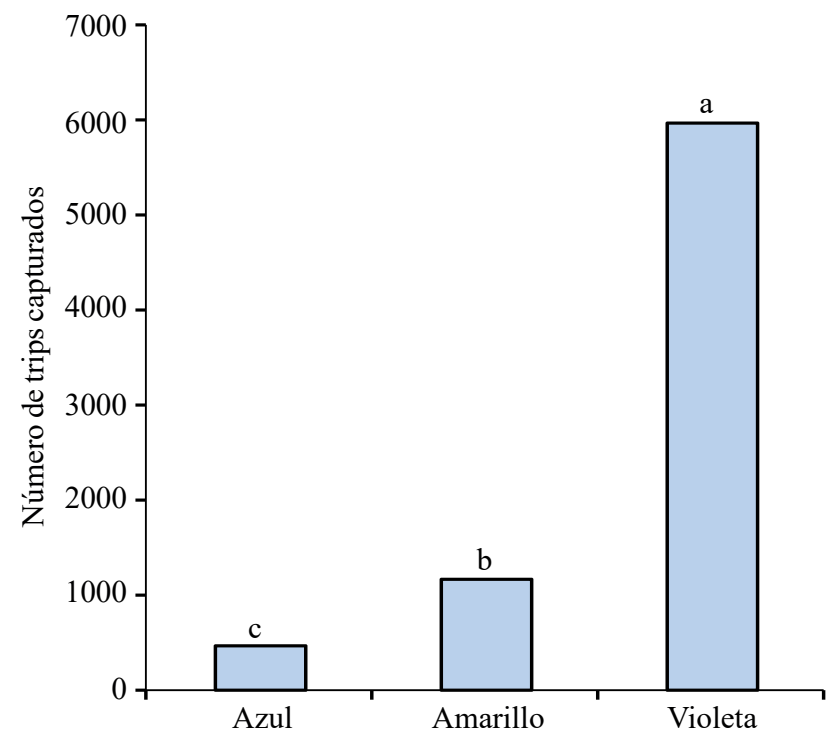

Figura. 1a. Captura de trips con trampas de colores en el huerto de mango cv. Ataulfo "Cazanares".

Figure 1a. Thrips captured with colored traps in "Cazanares" orchard of mango cv. Ataulfo. 


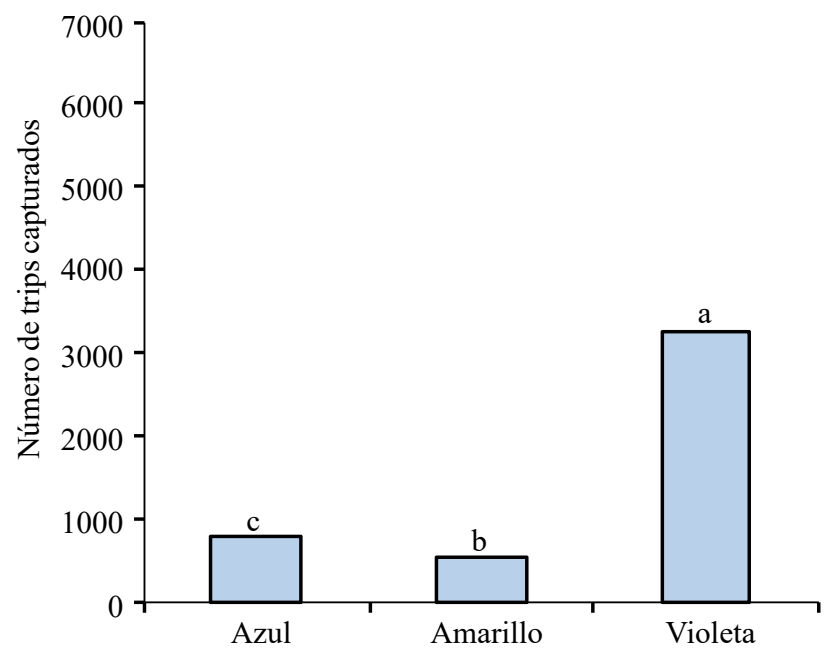

Figura 1b. Captura de trips con trampas de colores en el huerto de mango cv. Ataulfo "Palma de Oro".

Figure 1b. Thrips captured with colored traps in "Palma de Oro" orchard of mango cv. Ataulfo.

\section{CONCLUSIONES}

En base a nuestros resultados las trampas de color violeta podrían utilizarse para el monitoreo de las poblaciones de trips en el cultivo de mango cv. Ataulfo, y de esta manera se podría tener un mejor programa en las aplicaciones de plaguicidas.

\section{LITERATURA CITADA}

Chen, T. Y.; Chu, C. C.; Fitzgerald, G.; Natwick, E. R. and Henneberry, T. J. 2004. Trap evaluation for thrips (Thysanoptera: Thripidae) and hoverflies (Diptera: Syrphidae). Environ. Entomol. 33:1416-1420.

Chu, C. C.; Ciomperlik, M. A.; Chang, N. T.; Richards, M. and Henneberry, T. J. 2006. Developing and evaluating traps formonitoring Scirtothrips dorsalis (Thysanoptera:Thripidae). Fla. Entomol. 89:47-55.

Esquinca, A. H. A.; Quilantan, C. J. y Pérez, R. R. D. 2004. Los trips (Frankliniella cephalica) huésped inofensivo o amenaza real para el mango cv. Ataulfo en el Soconusco Chiapas. XXXIX Congreso Nacional deEntomología. Mazatlán, Sinaloa. 16-19 Mayo de 2004. Memorias. 217 p.
(Peña et al., 1993; González-Hernández et al., 1999) other species are attracted to blue color (Chen et al., 2004) but violet color has not been reported. In several thrips species, using colored traps represents a tool to record populations' fluctuations, as in the case of Frankliella occidentalalis (Pergande) in various horticultural and ornamental crops (Johansen, 2000).

\section{CONCLUSIONS}

Based on our results, violet traps could be used for monitoring thrips populations in mango cv. Ataulfo cultivation, and thus could have a better program in pesticide applications.

End of the English version

González-Hernández, H.; Méndez-Ramos, A.; Valle de la Paz,A. R. y González-Ríos, M. 1999. Selección de trampas de color y fluctuación de trips de aguacate en Michoacán, México. Revista Chapingo, Serie Horticultura. 5:287-290.

Hoddle, M. S.; Robinson, L. and Morgan, M. 2002. Attraction of thrips (Thysanoptera: Thripidae and Aelothripidae) to colored sticky cards in a California avocado orchard. Crop Prot. 21:383-388.

Johansen, R. M. 2000. The Mexican Frankliniella paracutinensis sp. nov. species assemblage, in the "intonsa group" (insecta, Thysanoptera: Thripidae). Acta Zool. Mex. 80:1-49.

Lee-Rodríguez, V.; Lerma-Molina, J. N. y Silos-Calzada, M. C. 2006. Diagnóstico fenológico nutrimental del magno (Mangifera indica L.) cultivar ataulfo en el Soconosuco Chiapas. Agrofaz. 6:121-136.

Peña, J. E. 1993. Pest of mango in Florida. Fourth International Symposium. Miami Florida, USA. Acta Horticulturae. 395 p.

Virgen, S. A.; Cruz, L. L. y Santiesteban, H. A. 1996. Evaluación de trampas de colores para el monitoreo de trips en huertas de mango (Mangifera indica) de la variedad Ataulfo en la región del Soconusco, Chiapas, México. Resumen de VIII Jornadas Científicas. Escuela de Ciencias Químicas. UNACH. 225-227 pp. 